УДК 343.85

DOI https://doi.org/10.32849/2663-5313/2020.4.59

Микола Семенишин,

канд. юрид. наук, докторант

Донецького юридичного інституту Міністерства внутрішніх справ Украӥни

\title{
ЗАПОБІГАННЯ НЕЗАКОННОМУ ЗАВОЛОДІННЮ ТРАНСПОРТНИМИ ЗАСОБАМИ ЯК ОБ'ЄКТ КРИМІНОЛОГІЧНОГО ДОСЛІДЖЕННЯ
}

У статті визначено зміст і сформульовано поняття «запобігання незаконному заволодінню транспортними засобами». Автором досліджено погляди кримінологічної науки на проблему елементного складу аналізованого злочину, що дало змогу більш чітко визначити й описати юридично закріплені ознаки незаконного заволодіння транспортними засобами, які зумовлюють належність иьього злочину до корисливої злочинності. Обгрунтовано, що основним безпосереднім об'єктом злочину, передбаченого ст. 289 КК Украӥни, є контрольоване використання транспортних засобів, перелічених у примітиі до ст. 286 КК України. Зазначені транспортні засоби є предметом иього злочину.

Ознаками діяння у разі скоєння злочину, передбаченого ст. $289 \mathrm{KK} \mathrm{Украӥни,} \mathrm{є} \mathrm{такі:} \mathrm{1)} \mathrm{воно} \mathrm{поля-}$ гає лише в активній поведіниі - дї; 2) дія проявляється в отриманні можливості керувати таким засобом; 3) поведінка винного є незаконною, він не має ані дійсного, ані уявного права на автотранспортний засіб, заволодіння яким здійснює; 4) заволодіння автотранспортним засобом здійснюється без чітко вираженого і справжнього волевиявлення власника або законного користувача иього засобу. При иьому воля потерпілого або ігнорується (у разі таємного заволодіння), або подавляється (у разі застосування насильства або погрози його застосування), або ж фальсифікується (у разі заволодіння шляхом обману). Заволодіння автотранспортним засобом -умисне протиправне вилучення такого засобу з будь-якою метою у власника або законного користувача всупереч їхньӧ волі (з місия стоянки або під час руху) шляхом запуску двигуна, буксирування, завантаження на інший транспортний засіб, примусового відсторонення зазначених осіб від керування, примушування ï до початку або продовження руху тощо. Таке заволодіння може бути вчинене таємно чи відкрито, шляхом обману чи зловживання довірою, із застосуванням насильства чи погроз.

Під «запобіганням заволодінню транспортними засобами» слід розуміти діяльність, яку здійснюють згідно із законом уповноважені державою особи та інші суб'єкти, що діють на добровільних засадах, із недопущення скоєння такого злочину, усунення його причин $і$ умов, переривання розпочатої злочинної діяльності на різних стадіях ї̈ здійснення, а також притягнення суб'єктів скоєння ивого злочину до кримінальної відповідальності та застосування до них іниих заходів кримінально-правового впливу.

Ключові слова: запобігання злочинам, транспортні засоби, право володіння, незаконне заволодіння.

Постановка проблеми та її актуальність. Реальне втілення конституційного положення про те, що Україна - правова держава, в якій утвердження і забезпечення прав і свобод людини є ії̈ головним обов’язком, передбачає перш за все створення в ній ефективної системи запобігання правопорушенням і злочинам у різних сферах суспільної діяльності, включаючи і злочини, що пов'язані 3 незаконним заволодінням транспортними засобами. Особливої актуальності зазначена тематика дослідження набуває у сучасних реаліях України у зв'язку з військовими подіями на її Сході, анексією Криму, а також негативними тенденціями розвитку злочинності, що мають місце з 2013 р. і дотепер, яка характеризується суттєвими кількісно-якіс- ними змінами у їі стані, структурі, динаміці та географії. Все це, зрештою, й зумовило відповідні зміни у змісті незаконного заволодіння транспортними засобами та, зокрема, стосуються всіх системоутворюючих ознак кримінологічної характеристики такого злочину. Так, у 2018 р. порівняно з 2002 р. їх кількість зросла на 45,8\%, а щодо 2014 р. - на $86,1 \%$. Загалом за цей період щорічно вчинялось більше 7 тис. незаконного заволодіння транспортними засобами в Україні. Зокрема, у 2002 р. було зареєстровано 8612 таких злочинів; 2005 р. - 8207; 2009 р. - 5184; 2012 р. 5838; 2014 р. - 12644; 2018 р. - 12801. Зазначене свідчить про неадекватну реакцію держави, її правоохоронних органів та всіх суб'єктів запобігання злочинам, що пов’язані 
із посяганням на безпеку руху та експлуатацію транспорту і право власності, непорушність якого гарантується Конституцією України. 3 іншого боку, така ситуація показує, що на практиці не досить, безсистемно та стереотипно використовуються розроблені в науці новітні технології із запобігання злочинам, включаючи незаконне заволодіння транспортними засобами.

Аналіз досліджень і публікацій. Методологічне підгрунтя щодо дослідження запобігання таким злочинам створили такі вітчизняні учені, як: О.М. Брисковська, Д.В. Горшков, В.А. Звіряка, Ю.Ф. Іванов, С.О. Колб, О.М. Корнєв, В.П. Кравченко, Я. В. Матвійчук, Б.Ф. Мицак, С.Є. Петров, К.О. Полтава, М.О. Свірін, С.С. Чернявський, Р.В. Щупаківський та ін.

Разом із тим вивчення кримінологічної характеристики незаконного заволодіння транспортними засобами та закономірностей розвитку такого злочину з часу прийняття у 2001 р. КК України показує, що досі на доктринальному рівні не досить досліджене поняття «запобігання незаконному заволодінню транспортними засобами», що має суттєве значення для вирішення теоретикоприкладних питань підвищення рівня протидії цьому суспільно небезпечному явищу 3 огляду наявних міжнародних підходів та практики.

Виклад основного матеріалу. Під «незаконним» у науково-практичних джерелах розуміють вчинене умисно, 3 будь-якою метою протиправне вилучення будь-яким способом транспортного засобу у власника чи користувача всупереч їхньої волі [1, с. 568]. Такий підхід фактично співпадае зі змістом примітки до ст. 289 КК України [2] і по суті не розширює знання суб'єкта пізнання щодо цього терміна.

Більш предметно до вирішення цього питання підійшов С.С. Яценко, який запропонував під незаконним заволодінням розуміти протиправне вилучення транспортного засобу із чужого володіння всупереч волі власника чи користувача i встановлення тим самим тимчасового чи постійного розпорядження вилученим видом транспорту для задоволення власних чи потреб інших осіб [3, с. 599]. Навпаки, М.І. Мельник та М.I. Хавронюк у науково-практичному коментарі КК України з цього приводу лише зауважили, що поняття незаконного заволодіння транспортним засобом дано у п. 1 примітки до ст. 289 КК, не давши його розширеного тлумачення [4, с. 686]

Своєю чергою П.П. Андрушко вважає, що незаконне заволодіння транспортним засобом - це протиправне його вилучення у власника чи користувача суб'єктом злочину [5, с. 694-695], давши таким чином звужене тлумачення цього терміна.

Проте, як зазначає С.О. Колб, як у п. 1 примітки до ст. 289 КК, так і в різноманітних доктринальних виданнях ключовим для визначення поняття «незаконне заволодіння транспортним засобом» $є$ словосполучення «протиправне вилучення будь-яким способом транспортного засобу у власника чи користувача». А це, своєю чергою, дає змогу стверджувати, що безпосереднім об'єктом такого злочину виступає право власності, а додатковим - безпека руху та експлуатації транспорту [6, с. 10].

Ознаками діяння у вчиненні злочину, передбаченого ст. 289 КК України, є такі: 1) воно полягає лише в активній поведінці - дії; 2) дія проявляється в отриманні можливості керувати таким засобом; 3) поведінка винного $є$ незаконною, він не має ані дійсного, ані уявного права на автотранспортний засіб, заволодіння яким здійснює; 4) заволодіння автотранспортним засобом здійснюється без чітко вираженого і справжнього волевиявлення власника або законного користувача цього засобу. При цьому воля потерпілого або ігнорується (у разі таємного заволодіння), або подавляється (у разі застосування насильства або погрози його застосування), або ж фальсифікується (у разі заволодіння шляхом обману). Заволодіння автотранспортним засобом - умисне протиправне вилучення такого засобу з будь-якою метою у власника або законного користувача всупереч їхньої волі (з місця стоянки або під час руху) шляхом запуску двигуна, буксирування, завантаження на інший транспортний засіб, примусового відсторонення зазначених осіб від керування, примушування їх до початку або продовження руху тощо. Таке заволодіння може бути вчинене таємно чи відкрито, шляхом обману чи зловживання довірою, із застосуванням насильства чи погроз.

У разі вчинення незаконного заволодіння транспортними засобами угону не існує, а всі дії, пов'язані з незаконним посяганням на транспортні засоби, необхідно кваліфікувати за статтями, що передбачають кримінальну відповідальність за посягання на власність, а відповідну статтю КК (ст. 215-3; ст. 289 КК) необхідно з Кодексу виключити [7]. Проте $€$ й інший підхід, відповідно до якого не всі випадки незаконних посягань можна кваліфікувати як корисливі злочини, позаяк, як вважають ці науковці, обов'язковою ознакою складу злочину, пов'язаного з викраденням, $€$ корисливий мотив, тобто прагнення отримати матеріальну вигоду внаслідок скоєння 
злочину. Використання ж майна з наступним поверненням, у тому числі незаконне заволодіння транспортним засобом 3 метою «проїхатись» та інші аналогічні дії, не можуть розцінюватися як викрадення [7, с. 59].

3 такою позицією погодитись не можна. Так, жодна зі статей розділу VI Особливої частини КК України «Злочини проти власності» не передбачає такої обов'язкової ознаки складу злочину, як «корисливий мотив». Про неї йдеться лише у науковопрактичних коментарях до КК, а також у спеціальній постанові Пленуму Верховного Суду України з цих питань від 6 листопада 2009 р. № 10 «Про судову практику у справах про злочини проти власності [8], які до джерел законодавства не належать. Виходячи 3 цього та керуючись вимогами ч. 4 ст. 3 КК про заборону застосовувати закон про кримінальну відповідальність за аналогією, варто визнати, що корисливий мотив не може бути визначальною ознакою для кваліфікації діянь, пов'язаних з незаконним заволодінням транспортними засобами. Додатковим аргументом 3 цього приводу виступає вжите у статтях розділу VI Особливої частини КК України та у ст. 289 КК слово «заволодіння», яке є об'єднуючим для цих складів злочинів з огляду на зазначену проблематику.

I, насамкінець, важливим у цьому контексті є положення ст. 41 Конституції України, відповідно до яких кожен має право володіти, користуватися і розпоряджатися своєю власністю. При цьому ніхто не може бути протиправно позбавлений права власності. Право власності є непорушним [9].

Таким чином, з урахуванням зазначеного та 3 метою упорядкування норм Особливої частини КК необхідно: а) ст. 289 КК України виключити з розділу ХІ КК; б) доповнити розділ VI КК ст. 198-1 «Незаконне заволодіння транспортним засобом» у редакції нині чинної ст. 289 КК; в) примітку 1 до ст. 198-1 викласти в такій редакції: «Під незаконним заволодінням транспортним засобом у цій статті слід розуміти вчинення умисного посягання на право власності особи чи користувача цього засобу всупереч їхньої волі».

Наступним системоутворюючим елементом у цьому словосполученні є поняття «запобігання». Як показали результати аналізу юридичної літератури, зазначений термін вживають поряд з такими поняттями, як «боротьба зі злочинністю», «попередження», «профілактика», «протидія», «соціальний контроль за злочинністю» та ін. За всієї різноманітності доктринальних підходів до зазначеної проблематики варто погодитись з висновком, якого дійшли О.М. Бандурка та Л.М. Давиденко: найбільш об'ємним за змістом і спрямованістю із зазначених вище $€$ термін «протидія злочинності», основними складниками якого є: а) кримінально-правовий аспект боротьби зі злочинністю; б) кримінологічний аспект або попередження злочинів на підставі усунення, послаблення і нейтралізації криміногенних факторів $[10$, с. 89$]$.

У широкому розумінні під протидією злочинності В.М. Куц розуміє складне соціально-правове явище та поняття про нього, в якому відображається теорія і практика специфічної державно-управлінської діяльності та приватних ініціатив, спрямованих на недопущення вчинення злочинів, усунення ï причин і умов, переривання розпочатої злочинної діяльності чи злочинного діяння на різних стадіях їх здійснення, притягнення суб'єктів їх вчинення до кримінальної відповідальності і застосування до них заходів кримінально-правового впливу [11, с. 14-15]. На думку О.М. Литвинова, з якою можна погодитись, поняття «протидія злочинності» може тлумачитись як реакція суспільства на злочинність. При цьому термін «реакція» включає в собі як кримінально-правовий вплив, так і кримінологічний вплив на злочинність [12, с. 6-7].

У межах кримінально-правового аспекту запобігання злочину, передбаченого ст. 289 КК, здійснюється шляхом: а) виявлення зазначених суспільно небезпечних діянь та їх реєстрації в установленому порядку (ст. 214 КПК); б) кримінального переслідування осіб, що вчинили незаконне заволодіння транспортним засобом, включаючи членів організованих злочинних угруповань; швидке, повне і неупереджене розслідування та судовий розгляд 3 тим, щоб кожний, хто вчинив таке кримінальне правопорушення, був притягнутий до відповідальності в міру своєї вини (ст. 2 КПК); в) застосування справедливого кримінального покарання за скоєння злочину, що пов'язаний з незаконним заволодінням транспортним засобом (ст. 289 КК); г) виправноресоціалізаційного впливу на засуджених (ст. 6 КВК) для досягнення мети кримінального покарання (ст. 50 КК) та кримінальновиконавчого законодавства (ст. 1 КВК); г) організації та реалізації заходів оперативно-розшукового супроводу слідчих (розшукових) та негласних слідчих (розшукових) дій (розділ III КПК), а також здійснення процесу кримінального переслідування винних у скоєнні злочину, зазначеного в ст. 289 КК України.

Незаконне заволодіння автотранспортним засобом посягає на відносини, що забезпечують безпеку дорожнього руху механічного 
транспорту та на відносини власності на автотранспортний засіб. Шкідливі наслідки у вигляді обернення автотранспортного засобу на користь винного чи інших осіб повністю охоплюються складом цього злочину. Додатково кваліфікувати діяння ще й за статтями, які передбачають кримінальну відповідальність за злочини проти власності, не потрібно - відносини власності на автотранспортний засіб уже поставлені під охорону ст. 289 КК України. Однак це не виключає можливості ідеальної сукупності незаконного заволодіння автотранспортним засобом з іншими кримінальними правопорушеннями. На думку В.В. Смельяненка, такі ситуації можливі, коли незаконне заволодіння автотранспортним засобом є способом вчинення іншого кримінального правопорушення, наприклад, викрадення вогнепальної зброї, бойових припасів, вибухових речовин, вибухових пристроїв чи радіоактивних матеріалів (ст. 262 КК України), викрадення наркотичних засобів, психотропних речовин або їх аналогів (ст. 308 КК України), що знаходяться в автотранспортному засобі, тощо [13, с. 200-201].

Своєю чергою кримінологічний аспект запобігання незаконному заволодінню транспортним засобом реалізується в основному шляхом недопущення такого суспільно небезпечного діяння [11, с. 14-15]. Це зумовлено, з одного боку, метою кримінального покарання (ст. 50 КК), одним зі структурних елементів якого $€$ запобігання вчиненню нових злочинів як засудженими, так і іншими особами, а з іншого боку, зміст такої проблеми детермінований метою, що визначена в кримінальновиконавчому законодавстві України (ст. 1 КВК та ст. 1 Закону України «Про оперативно-розшукову діяльність»). При цьому важливе місце в системі запобігання злочину, передбаченого в ст. 289 КК, належить індивідуально-профілактичному запобіганню [14, с. 118] та заходам віктимологічного запобігання [15].

Наступним системоутворюючим елементом терміна «запобігання незаконному заволодінню транспортними засобами» є поняття «транспортні засоби». Відповідно до примітки до ст. 286 КК України під транспортними засобами слід розуміти всі види автомобілів, трактори та інші самохідні машини, трамваї і тролейбуси, а також мотоцикли та інші механічні транспортні засоби.

Як свідчить практика, винні особи, у тому числі організовані злочинні групи в Україні, вчиняють цей злочин, як правило, шляхом заволодіння всіма видами автомобілів та мотоциклів [16, с. 71-72].

Звичайно, що ключовим у понятті «запобігання незаконному заволодінню тран- спортними засобами» $€$ термін «запобігання». На думку В.В. Голіни, запобігання злочинності - це сукупність різноманітних видів діяльності і заходів у державі, спрямованих на вдосконалення суспільних відносин з метою усунення негативних явищ та процесів, що породжують злочинність або сприяють їй, а також недопущення злочинів на різних стадіях злочинної поведінки [17, с. 142].

Загальними у визначенні поняття «запобігання злочинності» були такі постулати, якими керувались його автори: 1) запобігання злочинності - це перспективний напрям злочинності; 2) основою системи запобігання злочинності є правова держава; 3) запобігання злочинності розуміється як єдність загальносоціальних і спеціальних видів діяльності держави і суспільства; 4) обов'язковість участі громадськості в запобіганні злочинності; 5) мета системи запобігання злочинності - істотне зниження кількісних і позитивні зміни якісних показників злочинності в Україні; 6) ресурсне забезпечення запобігання злочинності; 7) моніторинг злочинності й ефективності заходів їі запобігання [18, с. 16].

Загальновизнаними в науці також є підходи до класифікації запобіжних заходів, тобто розподіл явищ, понять, заходів за класами залежно від загальних ознак або класифікатора, який здійснюється на теоретичному та практичному рівнях з метою належного впорядкування змісту запобігання злочинам, чіткого визначення рівня і напрямів діяльності суб'єктів запобігання злочинам, їх компетенції, а також природи самих запобіжних заходів. При цьому учені у своїх роботах пропонують різні класифікації запобіжних заходів з урахуванням тих цілей, які перед ними ставляться. Зокрема, зазначені заходи класифікуються: за рівнем, масштабом, змістом, суб'єктами та ін. [17, с. 143]. Як з цього приводу зауважив В.В. Голіна, запобігання злочинності як важливий елемент інтегративної системи організованої протидії злочинності включає в себе безліч різноманітних запобіжних заходів, чітких визначень рівнів і напрямів запобіжної діяльності суб'єктів, їх компетенції, природи самих заходів тощо [18, с. 17]. Так, за рівнем у науці розрізняють: а) загальносоціальні; б) спеціально-кримінологічні; в) індивідуальні запобіжні заходи. За масштабом виділяють: 1) заходи, які здійснюються у територіальному розрізі; 2) заходи, що вчиняються на окремому об'єкті; 3) заходи, спрямовані щодо групи осіб. За змістом заходи із запобігання злочинам класифікують на: а) заходи соціально-економічного характеру; б) заходи соціально-демографічного спрямування; 
в) заходи технічного, екологічного та іншого характеру; г) заходи правового спрямування. За суб'єктами запобіжні заходи поділяються на: 1) заходи, що здійснюються органами всіх гілок влади; 2) заходи, що реалізуються організаціями, установами та трудовими об'єднаннями; 3) заходи, в яких беруть участь окремі громадяни. За об'єктами запобігання здійснюється стосовно видів злочинів, щодо яких вчиняють свою діяльність суб'єкти запобігання злочинам [17, с. 143].

При цьому знову ж таки варто зазначити, що в науці є й інші підходи до класифікації запобіжних заходів у сфері боротьби зі злочинністю, проте їх суть є незмінною: вони спрямовані на недопущення скоєння злочину на ранніх його стадіях (готування (ст. 13 КК) та замаху на злочин (ст. 14 КК)). Зазначені теоретико-прикладні підходи й були використані для виведення у цій статті поняття «запобігання незаконному заволодінню транспортними засобами», під яким у більш вузькому (суто прагматичному) підході слід розуміти сукупність різноманітних видів діяльності суб'єктів запобігання злочинам, що здійснюються на підставі нормативноправових актів і визначених у законі принципів з метою недопущення протиправного заволодіння винною особою (чи групою осіб у співучасті) на різних стадіях вчинення злочину тим предметом, що визначений у законі, та посягання на який є суспільно небезпечним та караним, а також діяльність із нейтралізації, блокування, усунення тощо детермінант, що породжують або зумовлюють цей вид суспільно небезпечної поведінки у суспільстві.

\section{Висновки}

Теоретичне та практичне значення визначення на доктринальному рівні змісту та суті зазначеного поняття полягає в такому: на теоретичному рівні розширені межі знань щодо такого суспільно небезпечного діяння, а також обгрунтовано певні шляхи його подолання; на практичному рівні створено відповідні алгоритми дій, спрямованих на удосконалення механізму запобіжної діяльності; необхідність формування правових дефініцій зумовлюються наявністю проблем у запобіганні тому чи іншому виду злочину (у цьому разі незаконному заволодінню транспортними засобами) та низькою ефективністю діяльності у цьому напрямі; чітке визначення будь-якого поняття дає можливість уточнити цілі, завдання та параметри діяльності (межі, повноваження, можливості) усіх суб'єктів запобігання злочинам (як спеціалізованих, так і неспеціалізованих); формулювання поняття «запобігання незаконному заволодінню транспортними засобами», своєю чергою, дає змогу уточнити зміст кримінологічної характеристики цього злочину, а також усіх рівнів запобіжної діяльності у цьому сенсі (загальносоціального, спеціально-кримінологічного та індивідуального); наукове обгрунтування змісту зазначеного поняття та його системоутворюючих ознак, крім цього, створює відповідне підгрунтя для розробки проблем віктимологічного запобігання та латентності такого виду злочинів.

Під «запобіганням заволодінню транспортними засобами» слід розуміти діяльність, яку здійснюють згідно із законом уповноважені державою особи та інші суб'єкти, що діють на добровільних засадах, із недопущення скоєння такого злочину, усунення його причин і умов, переривання розпочатої злочинної діяльності на різних стадіях їі здійснення, а також притягнення суб'єктів скоєння цього злочину до кримінальної відповідальності та застосування до них інших заходів кримінально-правового впливу.

\section{Список використаних джерел:}

1. Кримінальний кодекс України. Науковопрактичний коментар: у 2 т. / за заг. ред. В.Я. Тація B.I. Борисова, В.І. Тютюгіна. 5-те вид., допов Харків : Право, 2013. Т. 2: Особлива частина. 2013. $1040 \mathrm{c}$

2. Кримінальний кодекс України : Закон від 05 квіт. 2001 р. № 2341-III. / Верховна Рада України. URL: http://zakon5.rada.gov.ua/laws/ show/2341-14.

3. Науково-практичний коментар Кримінального кодексу України. 4-те вид., переробл. та доповн. / за заг. ред. С.С. Яценко. Київ : А.С.К., $2006.848 \mathrm{c}$.

4. Науково-практичний коментар Кримінального кодексу України / за ред. М.І. Мельника, М.I. Хавронюка. 9-те вид., перероб. та допов. Київ : Юрид. думка, 2012. 1316 с.

5. Науково-практичний коментар до Кримінального кодексу України / за заг. ред. П.П. Андрушка, В.Г. Гончаренка, Є.В. Фесенка. 2-ге вид., переробл. та доповн. Київ : Дакор, 2008. $1428 \mathrm{c}$

6. Колб С.О. Кримінально-правова характеристика незаконного заволодіння транспортними засобами в Україні. Науковий вісник Херсонського державного університету. Серія «Юридичні науки». 2015. Вип. № 1. Т. 4. С. 9-15.

7. Свірін М.О. Запобігання органами внутрішніх справ незаконному заволодінню транспортними засобами : дис... канд. юрид. наук : 12.00.08. Київ, 2010. 227 с.

8. Про судову практику у справах про злочини проти власності : Постанова Пленуму Верховного Суду України від 6 листопада 2009 р. № 10. / Верховна Рада Украйни. URL: https:// zakon.rada.gov.ua/laws/show/v0010700-09. 
9. Конституція України : Закон від 28 черв. 1996 р. № 254к/96-ВР. / Верховна Рада України. URL: http://zakon2.rada.gov.ua/laws/show/ $254 \% \mathrm{D} 0 \% \mathrm{BA} / 96-\% \mathrm{D} 0 \% \mathrm{~B} 2 \% \mathrm{D} 1 \% 80$.

10. Бандурка А.М., Давиденко Л.М. Преступность в Украине: причины и противодействие монография. Харьков : Основа, 2003. 368 с.

11. Проблеми протидії злочинності : підручник / Кальман О.Г., Козьяков І.М., Куц В.В. та ін. за ред. проф. О.Г. Кальмана. Харків : вид-во ТОВ Фірма «Новасофт», 2010. 352 с.

12.Литвинов А.Н., Давыденко Л.М., Давыденко М.Л. Противодействие преступности : учебное пособие. Киев : «Хай-Тек Пресс», 2011. $200 \mathrm{c}$.

13. Ємельяненко В.В. Деякі питання кваліфікації незаконного заволодіння транспортним засобом. Ученые записки Таврического начионального университета им. В.И. Вернадского. Серия «Юридические науки». 2007. Т. 20 (59). № 2. С. 200-204.
14. Профілактика злочинів : підручник / О.М. Джужа, В.В. Василевич, О.Ф. Гіда та ін. ; за заг. ред. О.М. Джужи. Київ : Атіка, 2011. 720 с.

15. Джужа А.О. Теоретичні та практичні засади віктимологічного запобігання злочинам в Україні : автореф. дис. докт. юрид. наук : 12.00 .08 «Кримінальне право та кримінологія; кримінальновиконавче право». Харків : Харк. нац. ун-т внутр. справ, 2017. 35 с

16. Іванов Ю.Ф. Незаконне заволодіння транспортним засобом: кримінально-правовий та кримінологічний аспекти : практичний посібник. Київ, 2008. 108 с.

17. Кримінологія : підручник / В.В. Голіна, Б.М. Головкін, М.Ю. Валуська та ін. ; за ред. В.В. Голіни, Б.М. Головкіна. Харків : Право, 2014. $440 \mathrm{c}$.

18. Голіна В.В. Запобігання злочинності (теорія і практика) : навчальний посібник. Харків : Нац. юрид. акад. України, 2011. 120 с.

The article defines the content and formulates the concept of "prevention of illegal seizure of vehicles". The author explores the viezes of criminological science on the problem of elemental composition of the analyzed crime and allowed to more clearly identify and describe the legally fixed signs of unlaw ful seizure of vehicles that determine the belonging of this crime to self-serving crime. It is substantiated that the main direct object of the crime under Art. 289 of the Criminal Code of Ukraine, is the controlled use of vehicles listed in the note to Art. 286 of the Criminal Code of Ukraine. These vehicles are the subject of this crime.

Signs of action in committing a crime under Art. 289 of the Criminal Code of Ukraine are as follows: 1) it consists only in active behaviour - actions; 2) the action is manifested in the ability to control such a tool; 3) the conduct of the perpetrator is illegal, he has neither a valid nor an imaginary right to the vehicle he seizes; 4) seizure of a motor vehicle is carried out without clearly expressed and valid will of the owner or legal user of this vehicle. In this case, the will of the victim is either ignored (in secret possession), or suppressed (in the use of violence or threat of its use), or falsified (in possession by deception). Seizure of a motor vehicle is the deliberate unlawful removal of such vehicle for any purpose from the owner or legal user, against their will (from the parking place or while driving) by starting the engine, towing it, loading it on another vehicle, forcibly removing these persons from driving, forcing them to start or continue moving, etc. Such seizure can be done secretly or openly, through fraud or abuse of trust, with violence or threats.

"Prevention of seizure of vehicles" should be understood as activities carried out by law authorized by the state persons and other entities acting on a voluntary basis, to prevent the commission of this crime, to eliminate its causes and conditions, to interrupt its started criminal activity committing, as well as bringing the subjects of committing this crime to criminal responsibility and applying to them other measures of criminal law influence.

Key words: crime prevention, vehicles, right of ownership, unlawful taking. 